\title{
Community Partnerships: \\ Elgin Business Resource Centre Satellite Office Project
}

\section{Marilyn Crewe Ec. D.}

Economic Development professionals are challenged every day to do more with less and justify each activity and expenditure. Partnerships become vital to leverage assets and efficiencies and, as a result, reach greater strategic objectives. The need to address identified issues in the community and find strategic partners to meet those needs can pave the road for economic development one business at a time.

This environment for opportunity opened the door to attempt a satellite office project between a Community Futures Office, an upper tier municipality and a private company. Through partnership and innovation, entrepreneurs in Elgin County now receive improved access to support and counselling for starting a business and creating jobs.

Keywords: partnership, strategy, Community Futures, Elgin County, satellite office

\section{Background}

Community Futures Development Corporations (CFDC) provide their communities with a variety of services including business development loans, technical support, training and information. In addition to the business development component, CFDCs/CBDCs involve themselves in a wide array of community initiatives, including strategic planning processes, research and feasibility studies, and the implementation of a diverse range of community economic development (CED) projects.

Community Futures (CF) offices across Canada have been provided with federal funding to fulfill the mandate of business support for over 25 years. While the parameters of the program have remained stable, the desire for a new funding model linked to performance has been implemented in the past two years. This funding model has caused CF offices to re-evaluate satellite offices as funding was halted for such services with the new funding model.

Overall funding for each office was reduced by half over a two year period. The CF offices were asked to provide annual targets for all areas of business services and additional funding would be directly linked to achieving those targets. Each office created a new business plan to direct these efforts and show community engagement to ensure strategic business development relevant to each CF region. 


\section{Elgin County}

Elgin County is situated on the north shore of Lake Erie and is made up of 7 lower tier municipalities (Figure 1). Along with the City of St. Thomas, the population is just over 87,000 people.

Manufacturing and agriculture are the dominant industries creating employment in Elgin County with trades, transport and equipment operators and sales and service taking the lead in overall occupations within those industries.

The County of Elgin Economic Development Plan 2011-2014 (MDB, 2011) provides the following overview of small business in the county:

- $56 \%$ of all businesses have no employees;

- $53 \%$ of businesses with employees have fewer than 5;

- most businesses with employees are in retail trade, construction, and agriculture; and

- manufacturing accounts for most large businesses.

Figure 1 - Ontario Locator Map for Elgin County

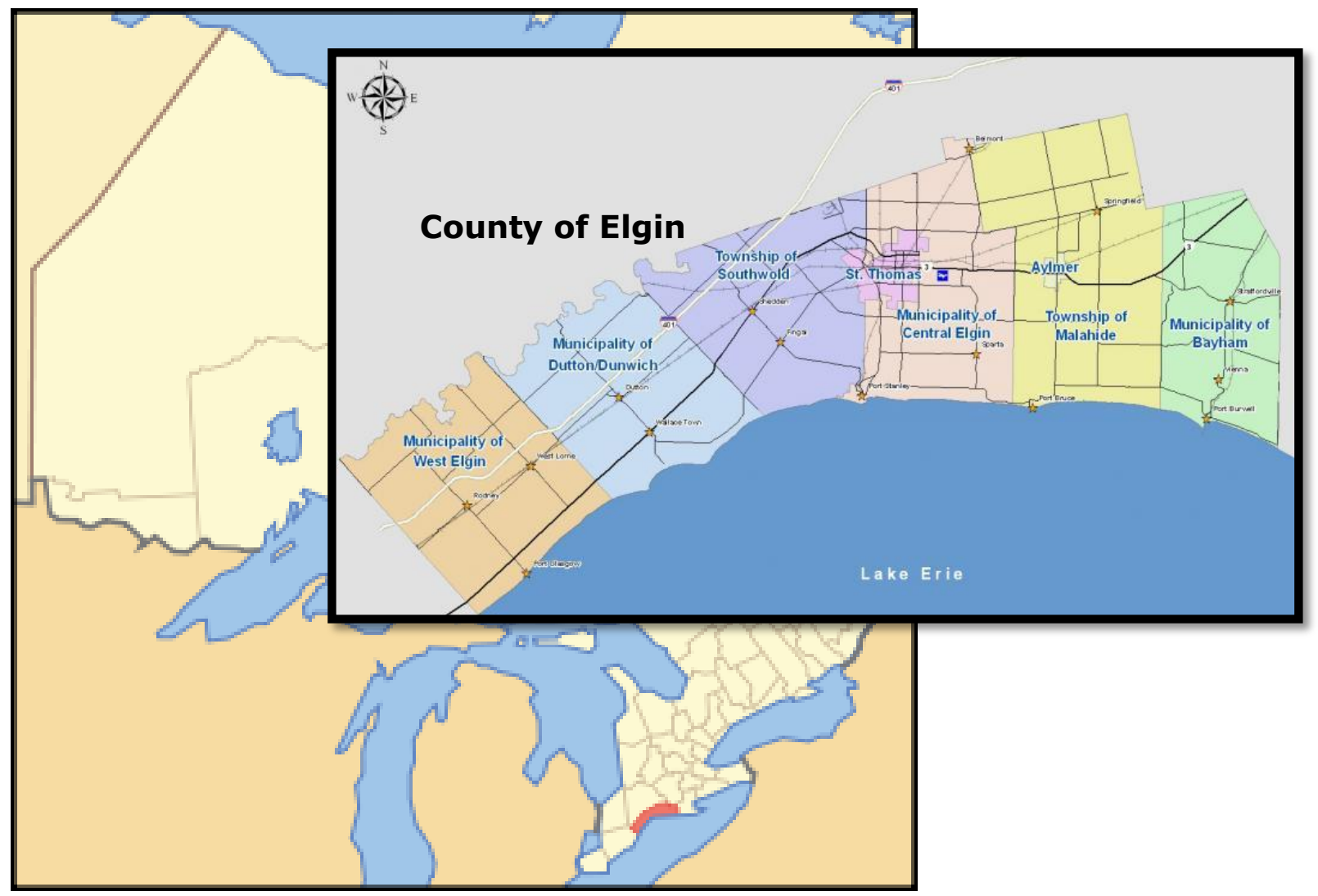

Source: Elgin Business Resource Centre 


\section{Elgin Business Resource Centre}

The Elgin Business Resource Centre is home to the Elgin Community Futures Development Corporation, Elgin/St. Thomas Small Business Enterprise Centre, Ontario Self Employment Benefits Program, Summer Company Program, and the Innovation Centre for Entrepreneurs, hereinafter collectively referred to as Elgin Business Resource Centre, or EBRC.

The role of EBRC is to support Elgin's local business communities. EBRC is a communitybased not-for-profit organization run by a board of local volunteers and staffed by professionals who encourage entrepreneurship and the pursuit of economic opportunities at a business and community level, which includes access to capital, business services, and project support through strategic community planning.

The community has been turning to EBRC for

- $\quad$ strategic community planning and socio-economic development;

- support for community-based projects;

- business information and planning services; and

- access to capital for small- and medium-sized businesses and social enterprises (OACFDC, 2014).

\section{Meeting Client Needs}

EBRC's mandate is to provide entrepreneurial services for St. Thomas and Elgin County. An internal review of EBRC statistics show that the farther from St. Thomas an entrepreneur lives, the less likely they are to access the services. As most businesses start out with a single entrepreneur and it is difficult or impossible for them to leave their place of work, site visits are a part of the services that EBRC provides. The Business Counsellors are available to meet with the entrepreneur at their business. However, in the past very few clients took advantage of the service and the 45 minute drive to St. Thomas was likely the main barrier. Further, EBRC labour force data shows that $80.4 \%$ of businesses in Elgin County have 0-4 employees. Each of these business owners might have difficulty getting away for an appointment and EBRC saw this as a missed opportunity to support new and growing businesses simply because they could not access the Centre's business counselling.

In 2009-2010, EBRC attempted an outreach program to meet the needs of clients in outlying areas. Business Counsellors advertised office hours one day a week in Straffordville (east end) and West Lorne (west end). Marketing was undertaken to promote the opportunity to access business counselling in the local area but still, very few people took advantage of this opportunity. EBRC suspects that the following factors impacted attendance. First, the entrepreneur needs to be the one to set the date and time, not the service provider. For example, if the satellite office was only open on Thursdays and that happened to be a delivery day for a small business, the entrepreneur would never be available to book an appointment. Second, the 
office space used was chosen by EBRC. A central location was selected based on EBRC's convenience, not partnership.

The need to investigate the feasibility of a satellite office was identified in both EBRC's 2009 and 2013 Strategic Plans (EBRC 2009, EBRC 2013) as one of three strategic objectives:

1. Diversity in provision of services.

2. Enhancement of business services and programs.

3. Determine the feasibility of a satellite office.

This strategic direction provided EBRC with the tools needed to develop a plan of partnership to better meet the needs of the outlying areas of Elgin County.

\section{Partnership Development}

\section{Elgin County}

The Elgin County Economic Development Department has been a strong partner with EBRC on several local initiatives, which allowed the development of trust between the two organizations. Not all the projects involved funding; some were committees and in-kind projects which showed the partners' strengths and priorities over time. When it came time to approach Elgin County Economic Development, the pathways had already been cleared by the history shared around the discussion table.

Success Factor: A key factor in the success of this project included understanding and aligning the Elgin County Economic Development Department's mandate with EBRC's mandate. By aligning the strategic direction of both organizations, EBRC was able to pitch the project as a way to help meet both parties' objectives and build success across Elgin County.

Preliminary discussion centred on a few key points. The ability to reach out to under-served entrepreneurs in Eastern Elgin County was pivotal. A list was created of the key performance indicators which could be attached to the satellite office. These indicators were:

1. jobs created,

2. businesses started,

3. general inquires,

4. in-depth consultations,

5. referrals, and

6. Loans generated.

There was also interest in tracking the postal codes at the time of an inquiry to track the reach of the satellite office. Over the course of the pilot project, this information was deemed less valuable than it initially appeared and was dropped. The overall feeling was favourable to try a pilot project, but the location was still uncertain. 


\section{Elgin Innovation Centre}

In Aylmer, Ontario, the former Imperial Tobacco processing plant was closed in 2007, leaving a large local facility empty. A group of local investors bought the facility and established the Elgin Innovation Centre, which comprises one million square feet of office, processing and storage space. The idea was not to fill the space with a single large manufacturer, but divide the space into flexible pieces based on many business owners' needs. Extensive renovations were made to improve the front office section and a couple of businesses associated with the investors moved into small corners of this massive property.

By 2012, the owners were looking to show the community what the location had to offer. The owners were pleased to be a part of the satellite office project and offered free space for two staff for the pilot year. A Memorandum of Understanding (see Appendix A) was drafted and the deadline was set for moving the EBRC office. Similar to the Elgin County Economic Development Department partnership, this one was not brand new either. One of the investors had worked on a building expansion project for EBRC.

\section{Figure 2 - Elgin Innovation Centre}

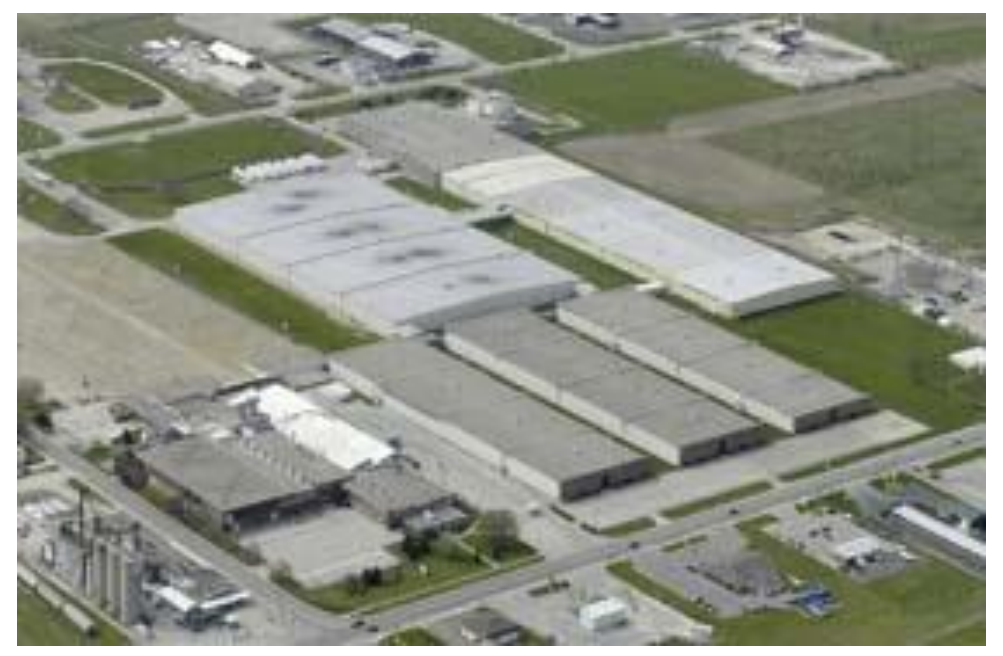

Source: http://www.elgininnovation.com/

\section{Deputation to Elgin County Council}

According to the EBRC 2011 Annual Report, the St. Thomas main office recorded 5,060 client inquiries and 2,026 in-depth consultations. This high level of demand was a catalyst for a pilot project to establish an EBRC satellite office in Aylmer, a town in the county's east end. Outlying areas in Elgin County would benefit from this location. The pilot project would improve accessibility to businesses needing support, as well as improve access for young entrepreneurs via Summer Company and Youth Entrepreneurship Partnership Program (YEP). 
Combining these benefits of location and increased access to programs and services (including the management and professional support at EBRC main office), Elgin County's Economic Development pilot project offered continued support and captured lost opportunities to help sustain the local economy.

Since 2010, the County of Elgin has provided support to one of the Elgin Business Resource Centre's core programs: the Elgin/St. Thomas Small Business Enterprise Centre (SBEC). The SBEC is a provincial program through the Ministry of Economic Development and Innovation providing entrepreneurial pre-start up support. In partnership with the Province, the County and City of St. Thomas committed annual matching contributions to SBEC and its programs.

This new County project was expected to build stronger collaboration and synergy amongst the business community at large. EBRC planned to establish a partnership with the Elgin Innovation Centre, and continue its collaborative approach to support economic development by maintaining relationships with local Chamber of Commerce, Fanshawe College, Thames Valley District School Board, Thames Valley Catholic School Board, Employment Services Elgin and Municipalities.

\section{Satellite Office Development}

\section{Organization and Management}

The satellite office is managed by EBRC and adheres to its governance and policies. All staff hiring, training and supervision are the responsibility of EBRC. The satellite office provides reports to the County of Elgin's Economic Development and Tourism Advisory Committee (CEEDTAC) who act as an advisory committee for the satellite office.

\section{Project Description}

Elgin County in partnership with the Elgin Business Resource Centre (EBRC) entered into a pilot project agreement to open an EBRC satellite office in Aylmer. The Elgin Innovation Centre in Aylmer agreed to house this satellite office at no base cost to EBRC. In order to accomplish this, EBRC contributed an estimated \$25,000 in time, management, training, miscellaneous and incidental costs. EBRC requested operational costs as outlined below.

For this pilot project, the operational expenses to the County included:

1. business counsellor salary,

2. administrative support salary,

3. benefits and contributions,

4. telephone and IT,

5. training and development, and

6. office expenses. 


\section{Purpose \& Objectives}

The Economic and Strategic Plans for Elgin County recognize the importance of entrepreneurship and business retention as being critical to the economic growth and sustainability of this area.

EBRC offers the following business services:

- counselling for businesses in planning and start-up phase (self-employment);

- counselling for businesses in retention and expansion phase;

- information on existing government programs for business (grants, training, etc.);

- assistance with the development of applications for access to government programs and funds;

- financial assistance in the form of loans;

- partnership and leveraging opportunities in business;

- advice through an accountant/lawyer referral service;

- access to mentorship and entrepreneur-specific resources;

- workshops and seminars;

- networking and professional development opportunities;

- guidance on licenses, permits, registration, regulations and other requirements;

- onsite business registration; and

- business incubation (EBRC, 2014).

In eastern Elgin County, the EBRC satellite office is dedicated to helping business owners and entrepreneurs succeed in today's ever-changing business market. Whether they are thinking about opening a business, formulating a business plan, or undergoing change in an established business, the EBRC satellite office offers assistance and access to the resources and human capital of the main office.

\section{Financial Summary:}

Business Counsellor: $\$ 50,000$ - Contract

Administrative Support: $\$ 40,000$ - Contract

Benefits and Contributions: $\$ 12,000$

Telephone and IT: $\$ 2,500$

Training and Development: $\$ 3,000$

Office Expenses: $\$ 2,500$

Final Total: $\$ 110,000$

The creation of a satellite office as a pilot project in Aylmer impacted the already over-utilized services of the Elgin Business Resource Centre. The expectation for service on the main centre in St. Thomas was anticipated to increase as promotion reached all areas of East Elgin. The satellite 
office staff managed the demand for business counselling however, the loans officer at the St Thomas office saw increased activity. As needed, additional staff support was provided from the main office to assist the satellite office.

This new pilot project and the operational expenses did not affect the County's existing partnership contribution to the Elgin/St. Thomas Small Business Enterprise Centre program.

At the end of the one year pilot project, an economic impact report was presented to Council. It was left at the County's discretion and initiative to enter into negotiations with EBRC to extend the satellite office project beyond its pilot phase.

\section{Operations}

Elgin County was willing to provide funding for the one year pilot with the provision of ongoing communication during the year. A Reporting Plan was created including monthly updates and activity reports from staff. This report was created using an Excel spreadsheet which satellite office staff completed as part of their job description.

Elgin County provided marketing for the pilot project. With a dedicated marketing and communication staff, Elgin County had the capacity to support the project throughout the year with newspaper ads, newspaper inserts, and a banner which straddled Talbot Street in Aylmer. Working with EBRC, Elgin County also created building signage and hired a sign which was placed at the side of the road near the entrance to indicate where the office was located.

Success Factor: Signage on the building proclaiming the partnership and a "now Open" banner over the entry were highly effective. This satisfied all partners as Elgin County was shown to be the funder, the Elgin Business Resource Centre was shown to be the operator, and EIC had the visibility of being open for business.

\section{Figure 3 - Satellite office street view}

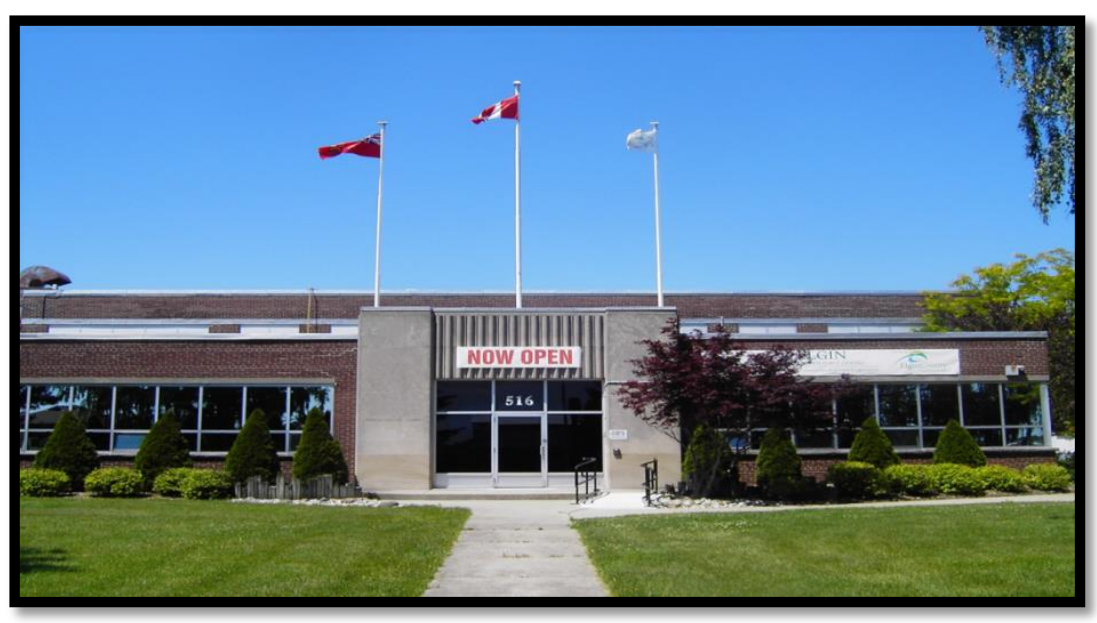

Source: Elgin Business Resource Centre 
EBRC was responsible for day-to-day operations. This involved hiring staff and setting up a functional office. Two staff members were hired for the pilot project - a business counsellor and a business assistant - and project management duties were added to the job description of EBRC's Community Economic Development (CED) Officer. The CED officer provided the monthly reports which were forwarded to the Elgin County Economic Development manager. The satellite office staff attended weekly staff meetings at EBRC's main office in St. Thomas to ensure open communications between the two offices.

A grand opening was planned with a full invitation list including local dignitaries from all levels of government. The event was held the Friday before opening day and included a ribbon cutting and speeches, as well as tours of the facility. This also was invaluable to all partners so that they could receive the exposure that was needed to gain leverage from the partnership. The EIC investors were pleased to drive up and see a parking lot filled with vehicles. There was energy and excitement in the community caused by the event.

Success Factor: As all levels of government and community were engaged in the opening and received the full story regarding the purpose of the satellite office, messaging distributed by word of mouth was consistent. Inclusion of all levels of government also ensured that appropriate referrals were made to ensure excellent client service.

The doors opened March 5, 2012. When the staff arrived, their first client was waiting for them to unlock the doors. Community engagement started right away. The Business Counsellor connected with the businesses already in EIC. The Chamber of Commerce was interested in partnering on events and workshops hosted at the satellite office. Other meetings were also hosted in the EIC boardroom. The booking of the boardroom was the responsibility of the business assistant. The business assistant also provided front desk reception support for EIC. Traffic was directed and phone calls were forwarded not just for EBRC business, but also in support of the entire facility. These tasks increased as local businesses started coming to see how they might fit into the EIC building.

Promotion of EIC was also placed on the County of Elgin website, which attracted local businesses as well as those from outside the region who were looking for space to start up or relocate their manufacturing and development companies.

Success Factor: As business clients visited the EIC site for business counselling, they were also shown the EIC facility and what that location had to offer. EIC agreed to give EBRC the equivalent of one month's rent to any client who signed a lease.

\section{Tracking and Reporting}

Early discussions included determining key performance indicators (KPIs) in cooperation with the funder to report back to County Council. Initial indicators included: 
- jobs created,

- businesses started,

- in-depth consultations where a discussion was held with a client regarding their business (concept or actual),

- inquiries and general business questions not regarding a specific business,

- referrals for loans and other programs, and

- number and total value of loans issued.

Success Factor: A database was created using Excel [Appendix B] which allowed tracking of daily client contact. Data collected included client name, business name and address, how the contact was made (i.e. phone, email, visit), and business sector. Jobs created and maintained were tracked as well as businesses started or maintained. This database calculated monthly totals and year-to-date totals which allowed for up-to-date KPI reporting to the funder at any time.

The reporting was provided monthly to fulfill the contract requirements. As a pilot project, there was uncertainty regarding how quickly clients would access the satellite office and what the demand would be overall. The partners each wanted value for their investment in local economic development. The County wanted to see businesses and jobs created, EIC wanted to have activity and leasing of their space and EBRC wanted to have staff in demand, providing business counselling and support to small businesses in East Elgin County.

At the six month mark all the partners reviewed the results. A deputation was made to County Council with a request to continue the East Elgin satellite office of EBRC on a three year agreement. At that time, EBRC reported economic impact (Table 1), client inquiries including repeat visits (Table 2), and in-depth consultations by sector (Table 3). Success stories from two businesses were provided to County Council reporting on jobs created and businesses created and expanded. The $\$ 110,000$ investment in EBRC Satellite office created 36 jobs for a cost of $\$ 3,056$ per job. During the deputation to Elgin County Council, EBRC proposed a one-year pilot satellite office for Western Elgin County.

\section{One Year Report}

The initial months generated approximately 45 enquiries per month, with this number increasing through the summer. Over half of the enquiries were in-depth consultations which included a broad range of businesses with diverse business needs. There were many successes, with the Aylmer office surpassing its first year goal with 38 jobs created and 14 businesses started in the county. Over a one year period, the Aylmer office had over 500 enquiries with over 530 indepth consultations (See Table 4). The office referred 33 individuals to the loans process and the SEB program. Considering that there was a $\$ 110,000$ investment in the EBRC East office and it created 38 jobs, the cost per job was $\$ 2,895$. 
The Elgin Business Resource Centre Satellite Office Pilot Project received the International Economic Development Council (IEDC)'s Excellence in Economic Development Award. The Economic Developers Association of Canada (EDAC) Marketing Awards also gave the project honourable mention.

Table 1 - Satellite Office Statistics

\section{Satellite Office Statistics}

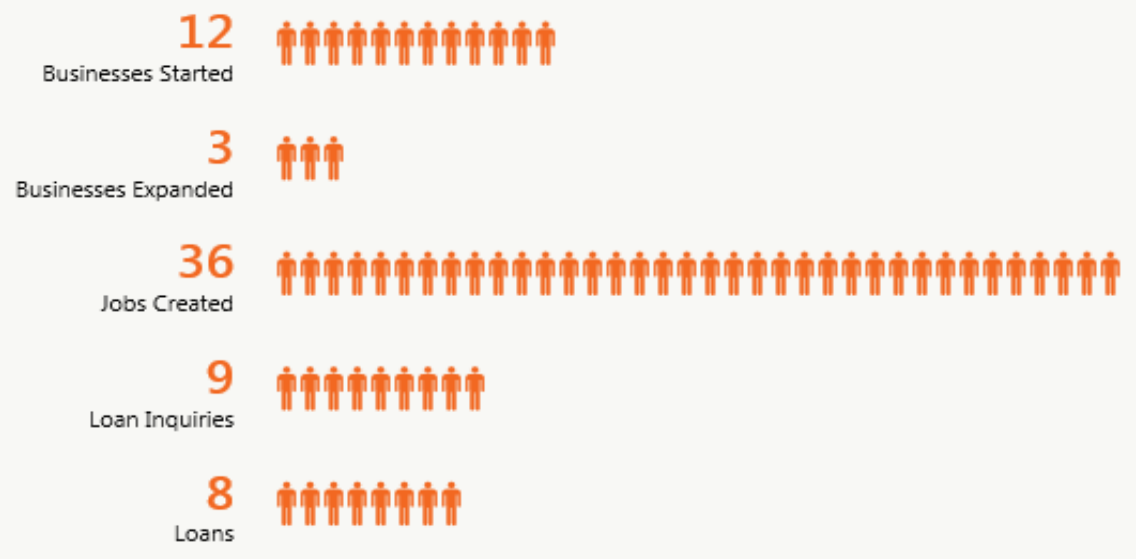

Source: Elgin Business Resource Centre

Table 2 - Client Inquiries

\section{Client Inquiries}

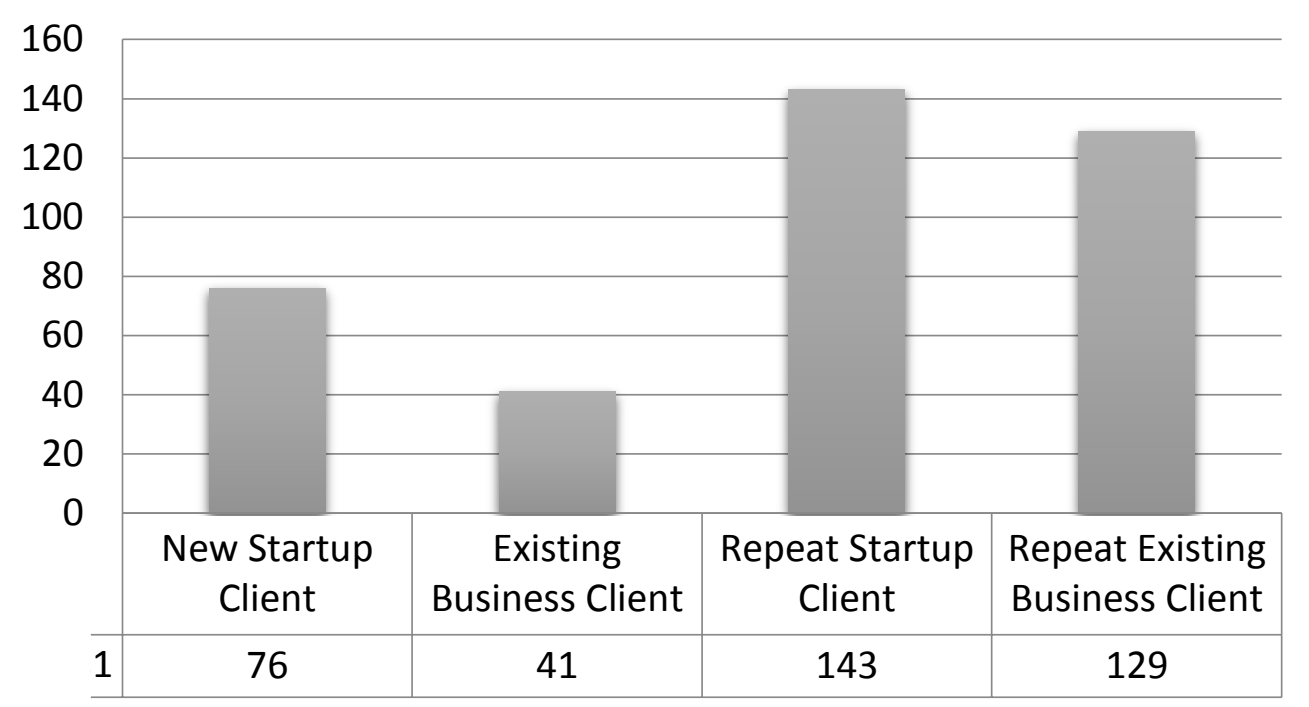

Source: Elgin Business Resource Centre 
Table 3 - Consultations by Sector

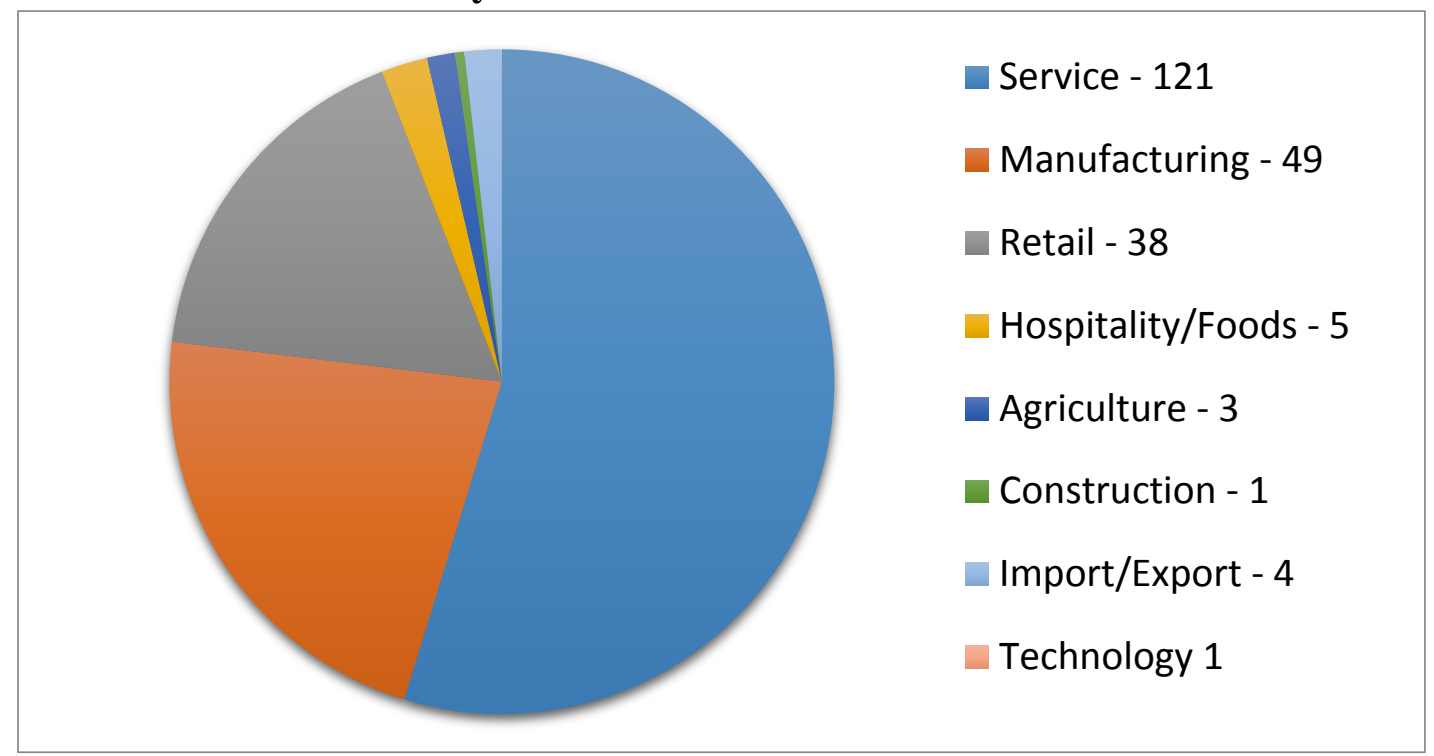

Source: Elgin Business Resource Centre

Table 4 - Year 1 Statistics

\section{Year End Statistics}

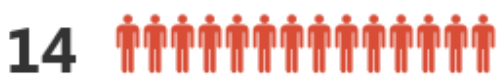

Businesses Started

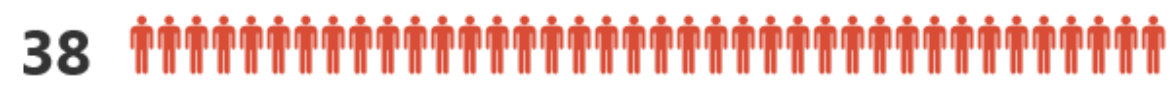
Jobs Created

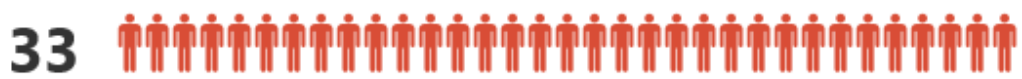
Referrals

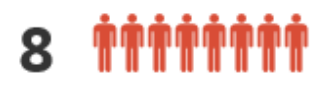
Loans

Source: Elgin Business Resource Centre

\section{Conclusion}

Elgin County Council approved three years of funding for the East Elgin satellite office and a one-year pilot project for West Elgin. The Elgin Innovation Centre agreed to continue the use of their office at no charge. A contract was signed between the County of Elgin and the Elgin Business Resource Centre and a revised memorandum of understanding was signed with EIC. 
Partnership development is key to reaching strategic objectives and maintaining fiscal responsibility. Prior to the successful launch of the satellite office reported here, key partners had already developed positive relationships by working on other projects. The successful launch of the Small Business Enterprise Centre, for example, included the County of Elgin and the City of St. Thomas. Partnering with a local business for the satellite office location provided leverage for the pilot project funding and allowed private enterprise to show vested interest in the community. As proof of the appreciation of the partnership, and while providing no-cost office space, the Elgin Innovation Centre provided the equivalent of one month's rent to EBRC after a client signed a lease. By exploring options and levering strategies among partners, the community can experience success. By involving all levels of government and the private sector, the Elgin Satellite Office project included key stakeholders who shared the responsibility for success.

Funder satisfaction was ensured through statistical measurement and timely reporting. The positive statistics speak for themselves - 14 businesses started and 38 jobs created through partnership and innovative thinking. The average investment from Elgin County was less than $\$ 3,000$ per job.

\section{Author Biography}

Marilyn Crewe is the Economic Development Officer for the Town of Neepawa, Manitoba. Formerly Community Economic Development Officer for the Elgin Business Resource Centre, Marilyn managed multiple projects including the Satellite office Pilot Project. Marilyn is a certified Economic Developer Ec.D. and holds the international designation in economic development C.Ec.D, and is also a Community Futures-certified Community Economic Development Coordinator.

\section{References}

Elgin Business Resource Centre (2009). Elgin Business Resource Centre Strategic Plan 2009.

Elgin Business Resource Centre (2011) Elgin Business Resource Centre 2011 Annual Report.

Retrieved from http://www.elginbusinessresourcecentre.com/wpcontent/uploads/2010/09/Annual-Report-Final-Version-3-small.pdf

Elgin Business Resource Centre (2013). Elgin Business Resource Centre Strategic Plan with Environmental Scan 2013-2016. Retrieved from http://www.elginbusinessresourcecentre.com/wp-content/uploads/2010/09/EBRC-Strategic-Plan2013-with-Environmental-Scan.pdf

Elgin Business Resource Centre (2014). Complete website. Retrieved from http://www.elginbusinessresourcecentre.com/ 
Elgin Middlesex Oxford Workforce Planning and Development Board (2012). 2012 Local Labour Market Plan. Retrieved from

http://www.workforcedevelopment.ca/sites/default/files/LLMP\%20Report\%20-

\%20WebVersion_0.pdf

Ontario Association of Community Futures Development Corporations (2014). Complete website. Retrieved from http://www.oacfdc.com/index.php/public-information

Millier Dickinson Blais (2011). County of Elgin Economic Development Strategy and Action Plan 2011 - 2014. Retrieved from

http://www.progressivebynature.com/sites/progressivebynature.com/files/documents/CountyofEl gin-EconomicDevelopmentStrategy-FinalReportAugust19th2011.pdf 


\section{Appendix A - Memorandum of Understanding}

\section{$\underline{\text { Elgin Innovation Centre }}$}

To: Elgin Business Resource Centre - St. Thomas, Ontario

From: Director of Elgin Innovation Centre - Aylmer, Ontario

$\underline{\text { Re: Memorandum of Understanding }}$

Please consider this confirmation that I, XXX XXXX, representing the Elgin Innovation Centre will provide the rental space of one office and the main reception area at 516 John St., Aylmer, Ontario to the Elgin Business Resource Centre (EBRC). The space will be made available at no cost to the EBRC. In addition to the space, the following items will be provided:

1. Reserved parking for two staff members

2. Snow plowing

3. Electrical - heat - cooling costs

4. Cleaning services including removal of sorted garbage/recycling

5. Access to phone system and Internet infrastructure (connection $\&$ hardware not included)

6. Access to furnished board room/meeting room with area for local art display

7. Access to lunch area

8. Computer location available for public access in lobby area

9. Suitable office mail delivery

Items not included in the free rent include the following:

1. Phone hardware and monthly service fees

2. Office furniture (desk/chair(s)/computer)

EBRC agrees to provide the following at no cost to the EIC:

1. A minimum of one full time staff person to provide basic receptionist services, additional services will be charged to tenants by EBRC on an hourly basis.

2. Consistent with the EBRC mandate, a full-time training personnel to assist business owners in Elgin County, including EIC tenants, in developing their businesses.

3. Regular promotion of the facility, rental opportunities and the joint services of EIC and EBRC.

4. Photocopier with code access for tenant use on a pay per use basis. Users invoiced by EBRC. It is understood by all parties that this is a one year pilot project. The basics of this agreement will be reviewed every 6 months and renewed annually subject to agreement by all parties. Should additional space be required by the EBRC to properly serve Elgin County a review of available space and the working arrangement will be conducted and, if all parties agree, an agreement worked out at that time. 


\section{Appendix B}

Satellite Office Client Tracking Sheet

\begin{tabular}{|c|c|c|c|c|c|c|c|c|c|c|c|c|c|c|c|c|c|c|}
\hline \multicolumn{19}{|c|}{ Satellite Office Tracking Sheet } \\
\hline \multicolumn{8}{|c|}{ Client Data } & \multicolumn{4}{|c|}{ Method of Contact } & \multirow{2}{*}{$\begin{array}{l}\text { Indicator } \\
\text { In Depth }\end{array}$} & \multicolumn{4}{|c|}{ Business Details } & \multicolumn{2}{|c|}{ Follow up } \\
\hline Date & Client Name & Business name & Address & Postal Code & Muncipality & Phone & Cell & Phone & Email & Appointment & Drop In & & Pre start & Registered & Maintain/Growth & Sucesstion & \begin{tabular}{|l} 
Type \\
\end{tabular} & Date \\
\hline & & & & & & & & & & & & & & & & & & \\
\hline & & & & & & & & & & & & & & & & & & \\
\hline & & & & & & & & & & & & & & & & & & \\
\hline & & & & & & & & & & & & & & & & & & \\
\hline
\end{tabular}

(Continued)

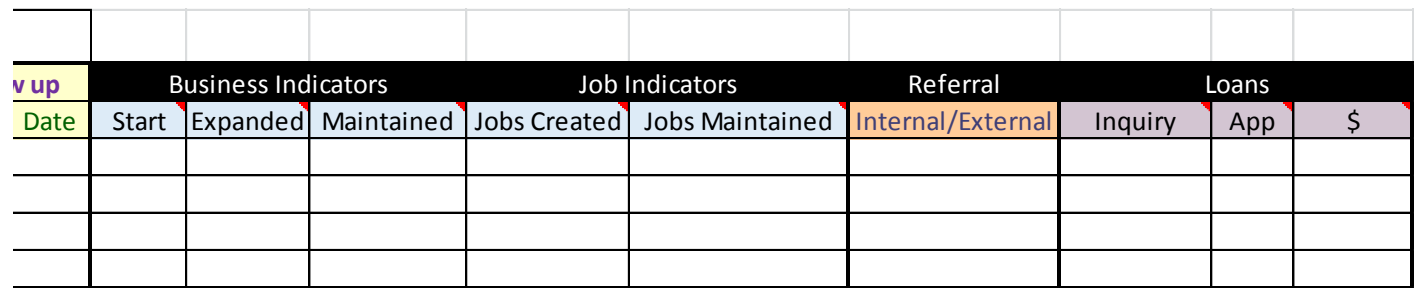

